\section{Intersections}

Canadian Journal of Music

Revue canadienne de musique
Intersections CANADIAN JOURAL OF MUSIC
REVUE CANADIENEE DE MUSIOUH

\title{
Constructing and Negotiating Chinese Cultural Identity in Diaspora Through Music and Martial Arts
}

\section{Colin McGuire}

Volume 38, numéro 1-2, 2018

URI : https://id.erudit.org/iderudit/1071676ar

DOI : https://doi.org/10.7202/1071676ar

Aller au sommaire du numéro

\section{Éditeur(s)}

Canadian University Music Society / Société de musique des universités canadiennes

\section{ISSN}

1911-0146 (imprimé)

1918-512X (numérique)

Découvrir la revue

Citer cet article

McGuire, C. (2018). Constructing and Negotiating Chinese Cultural Identity in Diaspora Through Music and Martial Arts. Intersections, 38(1-2), 105-119.

https://doi.org/10.7202/1071676ar
Résumé de l'article

Le club de kung-fu Hong Luck est une institution phare du quartier chinois de Toronto depuis plus de cinquante ans. Son programme inclut non seulement des cours d'auto-défense, mais également des cours de percussion pour l'accompagnement des démonstrations d'arts martiaux et de danse du lion. Le style fluide du club Hong Luck est un outil important dans la préservation, la transmission, et la promotion d'un patrimoine culturel. Les membres y négocient simultanément leurs identités de différentes façons. J'interprète donc le kung-fu comme une pratique flexible et dont la portée dépasse le combat physique. À partir d'une enquête de terrain au club Hong Luck, cet article emprunte à la sémantique cognitive et à la phénoménologie afin de montrer que le kung-fu, la danse du lion, et la musique de percussion contribuent à (re)construire les identités chinoises dans leurs aspects émergents et stratégiques.
Copyright ( C Canadian University Music Society / Société de musique des universités canadiennes, 2020
Ce document est protégé par la loi sur le droit d'auteur. L'utilisation des services d'Érudit (y compris la reproduction) est assujettie à sa politique d'utilisation que vous pouvez consulter en ligne.

https://apropos.erudit.org/fr/usagers/politique-dutilisation/ 


\title{
CONSTRUCTING AND NEGOTIATING CHINESE CULTURAL IDENTITY IN DIASPORA THROUGH MUSIC AND MARTIAL ARTS ${ }^{1}$
}

\author{
Colin McGuire
}

\section{INTRODUCTION}

Toward the end of winter 2009, I had my first encounter on the training floor with the former head instructor of Toronto's Hong Luck Kung Fu Club. ${ }^{2}$ Master Paul Chan (1932-2012) was in his seventies and typically taught only advanced students, so it was a surprise when he walked in during a beginner session. I had been a participant-observer at the club for about eight months and was working on a basic sequence of choreographed fighting moves. Master Paul watched for a few minutes and then called me over. He began to tell me-in no uncertain terms-how lousy my kung fu was: weak stances, stiff strikes, and, worst of all, the movement did not look Chinese enough. Being a Euro-Canadian, I thought his next comment might be about my ethnicity, but he surprised me by saying my martial arts looked Japanese! Master Paul then told me to "make it more Chinese," gave me some pointers, and sent me back to practising. This turned out to be a significant moment in my progress as a kung fu student, but no less so for my ethnography of the club and its music.

Since 1961, Hong Luck has been a bastion of tradition in one of the world's most cosmopolitan metropolises, promoting martial arts, lion dancing, and percussion music as embodied pathways to participation in Chinese culture. Briefly, the Southern Chinese lion dance is performed by kung fu practitioners using a large mask that goes over the lead dancer and an attached cape that drapes over the bent back of the tail dancer to form the body. The percussion ensemble used to accompany lion dancing consists of a drum, gong, and cymbals, and it is also played by kung fu practitioners. ${ }^{3}$ With reputedly over a thousand Hong Luck members and alumni, this not-for-profit institution has been an important part of Chinatown society for several generations. At the core of

1 This work was supported by the Irish Research Council (Grant GOIPD/2016/145).

2 Fieldwork was conducted in English and Cantonese. Where necessary, I have used the romanizations or translations that my consultants prefer, and I have provided Chinese characters in parentheses when additional linguistic clarity is helpful. (2016).

3 For an audiovisual example of lion dancing and percussion, see Hong Luck Kung Fu Club 
Hong Luck's kung fu curriculum are Cantonese martial arts from Southern China's Guangdong Province (formerly romanized as Canton), which is where the club's founders came from, as did most of Canada's early Chinese migrants (Li 1998).

Kung fu practitioners consider their musicking and dancing to be martial arts, rather than separate aesthetic practices. As such, I approach kung fu as a blurred genre in the sense proposed by Clifford Geertz (1980) to explain the increasing interdisciplinarity of academic work, which is a concept that has since been applied to other martial arts featuring a blend of combat, dance, and music, such as Brazilian capoeira (Downey 2002) and Indonesian/Malaysian pencak silat (Paetzold and Mason 2016). The transmission process at Hong Luck (and other Southern Chinese kung fu styles that include lion dance and percussion 4 ) inculcates combative dispositions towards musicking and dancing by physically, pedagogically, and cognitively rooting their entire system in martial arts. Lion dancing and percussion music are thus treated as extensions of kung fu, and my research reflects my consultants' perspective by privileging hand combat as the touchstone of the following discussion.

In this article, I contend that kung fu's blurred genre provides a physical and sonic way of being-in-the-world that offers flexible means for practitioners to embody Chinese Canadian identity. I argue that kung fu as interdisciplinary practice provides valuable tools that practitioners have used-and continue to use-in constructing their identities as Chinese Canadians, but that their experiences are varied, emergent, and contested. First, I present my research methods and the theoretical underpinnings of my argument. Next, I explain how training in martial arts, lion dance, and percussion engrains bodily and musical concepts of Chinese-ness. Finally, I give a brief history of Chinese experiences in Canada in order to frame the discourses of three Hong Luck members about their identities as Chinese Canadians.

\section{Methodology AND Theory}

This article is based on ethnographic research conducted between 2008 and 2016. The primary fieldwork site was the aforementioned Hong Luck Kung Fu Club, located in Toronto's Spadina/Dundas Chinatown. ${ }^{5}$ My research was meant to focus on the Southern Chinese martial percussion ensemble that consists of a large, single-sided barrel drum played with two short, stubby, wooden sticks; a hanging, flat-faced gong struck with a knobbed, wooden stick; and two or more pairs of handheld cymbals. Kung fu practitioners use these instruments to accompany both lion dancing and performances of fighting skills. The drummer is the leader of the ensemble, and so only more advanced practitioners play the drum. Before I was able to start learning the drum, I therefore had first to work my way through the basic curriculum of martial arts, then

4 For a general social history of Southern Chinese martial arts in China, see Judkins and Nielson (2015).

5 The Greater Toronto Area has two main Chinatowns in the city proper, as well as several suburbs with large Chinese populations. 
intermediate-level lion dance and metallophones. Methodologically, my participant observation thus tended towards performance ethnography (Wong 2008) because my consultants required me to go through an apprenticeship (Downey, Dalidowicz, and Mason 2014) in martial arts and lion dance as the path to learning their music.

As I advanced, I discovered that, to borrow a phrase from Timothy Rice (2003), kung fu drumming is learned but not taught. There were no formal lessons on the drum, but rather a transmission sequence that builds the knowledge and understanding of drumming, first through martial arts and then lion dance. Lion dance footwork is based entirely on the stances and stepping methods of kung fu, which is why prospective lion dancers are required to establish a foundation in Hong Luck's martial arts before being allowed into the lion dance class. Once in the lion dance class, students learn to say the drum rhythms as vocables in order to self-accompany practice without a drummer, as well as to communicate about the drum patterns in speech without the need for music theory. Traditionally, lion dancing functions as an exorcism that makes way for positivity, deploying danced martial arts to do battle with negative energies (Boretz 2011). Similarly, kung fu percussion's historical roots are as signalling instruments used to direct troop movements on the battlefield (Sun 1988). To this day, lion dance drummers act as sonic army generals, directing and motivating martial dance movements to achieve ritual efficacy (McGuire 2015). The whole transmission process for lion dance and drumming thus begins with, proceeds from, and rests on a foundation of martial arts.

As I already had twenty-five years of experience in other martial arts, I advanced fairly quickly, requiring three months of thrice-weekly kung fu basics classes before I was allowed to start lion dancing. Out of a class of about twenty beginners, only two of my classmates also expressed an interest in lion dance. Once the three of us satisfied our martial arts teachers with our foundation, we formed a new cohort and the lion dance instructor began working with us. We started by learning choreography, and our teacher would say the drum patterns as vocables while we practised. We also began learning to play simple supporting motifs on the gong and cymbals while our teacher played the drum. Once we had progressed to being able to do public lion dance performances, senior Hong Luck members encouraged us to translate our embodied knowledge of the rhythms into drumming. We received pointers and constructive criticism, but we were basically on our own in figuring it out. It took me about five years of kung fu and lion dancing before I was able to drum at a minimally acceptable level, and another three before my consultants considered me not too bad (they were not typically effusive with praise).

In order to interpret my findings in a way that will do justice to the intrinsic physicality of Hong Luck's practices, I turn to theories of embodiment and experience. The cognitive semantics work of philosopher Mark Johnson $(1987,1997 / 8)$ argues that the body is in the mind, reversing the dualistic Cartesian view that a separate mind resides in the body. Johnson proposes that corporeality provides the basis for meaning and undergirds all manner of cognition because "our conceptualization and reasoning are already grounded in 
patterns of bodily experience-in structures of our perception, bodily movement, and object manipulation" $(1997 / 8,98)$. He argues that before humans can develop abstract reasoning or the language to express it, they must first develop sensory-motor understandings of their being-in-the-world. Drawing on cognitive science, Johnson explains that humans develop meaning-making abilities before language, but that later use of words always refers back to embodied structures of understanding. Through a process of conceptual metaphor, the lived experiences of embodied knowledge are then abstracted and mapped onto other domains. Although the sound of music may be highly abstract, "musical meaning is not some second-class citizen forced to dwell outside the pristine realm of cognitive meaning; rather, it is paradigmatic of the way meaning emerges for us as embodied creatures" (100).

Johnson calls the principal categories of embodied knowledge image schemas, which are pre-linguistic patterns of experience that provide embodied structures for understanding the meanings of similar experiences through conceptual metaphor. Some examples of these image schemas include sourcepath-goal, containment, and balance, among others. One of Johnson's main examples is the force schema, which I will draw on in this article. It is basic to things like our understanding of gravity and object manipulation, but also undergirds more complex action like social obligation. I am not alone in tracing musical meaning to its roots in corporeal significance through image schemas, and musicologist Robert Walser (1991) has successfully applied the force schema to perceptions of power in the overdriven sound of heavy metal guitar. Appropriately, martial artists in general are very concerned with the use of force, and Hong Luck members in particular are concerned that this schema be expressed in a way that they understand as Chinese.

While image schemas develop before language, they continue to operate in not only linguistic reasoning, but also cultural expression. As an approach to understanding and explaining the phenomena of expressive culture, Harris Berger has developed a concept that he calls stance, which is "the affective, stylistic, or valual qualities with which a person engages with an element of her experience" (2009, xiv). He adapts Edmund Husserl's ([1913] 1962) phenomenological dictum that consciousness is always consciousness of something by suggesting that people are not simply aware of things, but rather are always grappling with their relationship to elements of existence. For Berger, the qualities of that engagement are rooted in social structures and cultural perspectives, guiding the negotiation of meaning in/as experience. Stance provides a framework for applying phenomenology to the study of expressive culture, which I use to help explain the meanings of the force schema in Hong Luck's Chinese martial arts. Kung fu has a tremendous emphasis on strong physical stances, which then provide the basis for a stance on meaning.

\section{Stances on Horse Stance}

The bodily deportment of Chinese martial arts is not like that of everyday life. Instead, people learn it through rigorous training that ultimately provides a 
distinctive way of being-in-the-world. Beginner classes at Hong Luck centre on an all-important position known as the horse stance. Physically, this posture involves planting one's feet about double shoulder-width apart and bending the knees into a deep squat that evokes the body position of horseback riding. In eight years of fieldwork, I never saw a beginner who had the strength, flexibility, balance, and/or endurance to hold the position for more than a few moments, but teachers required them to try to do so anyway-despite everybody's legs quivering from the strain. Over time, developing a strong horse stance is the catalyst that transmutes students' identities as they become practitioners of Chinese martial arts. While it may seem trite to reduce this process to a single pose, it would be difficult to over-exaggerate the importance of the horse stance; it is literally and figuratively the basis of kung fu, lion dancing, and drumming. That is to say, one needs to have developed a strong horse stance in order to perform martial arts demonstrations, do the lion dance, or play the drum because it is the foundational bodily position for all of these practices. Out of the rooted stability of the horse stance flow movement and sound, and so this posture is an embodied stance on being a Chinese martial artist.

Horse stance training is more than physical, calling for a body-mind shift. It forces students to ground themselves by sinking into the dāantihn (丹田, literally "cinnabar field"), which in Chinese medicine and meditative practices is the centre of the body, located slightly below the navel. Through repetition, the horse stance generates a shift such that the act of doing leads to a state of being. This process of centring is thus a path to being-in-the-world that Hong Luck members explicitly claim has deeply Chinese characteristics. For example, when Master Paul told me I needed to make my kung fu more Chinese, he first maintained that my stances needed more work and, second, that through experience I would understand what he meant.

Although the horse stance is found in other Asian martial arts, such as Japanese karate, Korean taekwondo, and Indonesian/Malaysian pencak silat, kung fu discourse contends that these are examples of the centre influencing the periphery. As the old saying goes, "All martial arts under heaven come from Shaolin," referring to myths about China's famous Shaolin Temple as the birthplace of all martial arts (Shahar 2008). Some scholars are skeptical about the historical accuracy of such beliefs (Henning 1999; Lorge 2012), but mythmaking and storytelling are important ways of establishing a stance on the nature of expressive culture (Green 2003).

Apart from the psycho-physical shift toward the daantihn as centre of body and mind, another interpretation of embodied centeredness in kung fu is more political. In Chinese, China's name means Middle Kingdom, placing it at the centre of the human world. When practitioners of Chinese kung fu's blurred genre centre themselves physically, they are embodying a stance on China's perceived position as the centre of the world. By displaying martial centred-ness that accords with Chinese perspectives on bodily being, they are performing the Shaolin origin myth with their bodies and thus reaffirming Chinese pre-eminence in global martial arts culture. From this perspective, a centred horse stance embodies the centrality of China, providing a way of 
being-in-the-world that exemplifies Chinese-ness through kung fu, lion dance, and drumming.

Master Paul may have insisted that a strong horse was the mark of properly Chinese martial arts, but people engage with their experiences of this position in various ways. Novice Hong Luck students tend to have a stance on training that weighs determination against avoidance as they alternate between trying to maintain a low horse stance and cheating to avoid the pain. Teachers echo Master Paul's insistence on the importance of the horse stance, and students have to contend with trust in the club, its lineage, and the transmission process. Once Hong Luck members are ready to start performing kung fu, lion dance, and/or drumming, they take a performative stance on the physical horse stance. For most of them, it becomes their power position: the foundation posture from whence all force, sound, and movement is issued. Some students, however, fail in their use of horse stance as the result of inexperience, stage fright, exhaustion, physical limitations, insufficient skill, laziness, or rebellion, thus grappling in various ways with their deficiency.

At Hong Luck, there is a wide tolerance for different levels of ability, recognizing that it takes time, effort, and talent to work through the curriculum, but the elders and instructors are careful about who gets to represent the club in performance. Spectators see, evaluate, and take a stance on the stances of kung fu and lion dance performers, so the club's reputation and honour are at stake should students not give an appropriate demonstration of their embodied stance on Chinese martial arts as a blurred genre. A drummer's horse stance, however, is heard more than seen (he is usually behind the drum); the ability to generate loud beats flows from his whole bodily structure. ${ }^{6}$ The Chinese character for drum (鼓) also means "to rouse," and powerful drumming feeds energy to performers of both kung fu and lion dance. Drummers thus take stances on the performances that they accompany through the ways that they provide musical accompaniment, playing louder and faster if a performer's vigour seems to be fading or drumming more gently to support an inexperienced performer who might otherwise be overwhelmed. Tellingly, Hong Luck members believe that strong drumming can compensate for a less powerful lion dance-but not vice versa.

\section{STANCES ON FORCE}

Master Paul also taught me that a strong horse stance was the prerequisite for issuing a characteristically Chinese style of force. Briefly, he wanted me to throw punches with a loose sort of power that would allow me to move fluidly before accelerating to a condensed snap just at the point of impact. At Hong Luck, this type of power is first learned through combat training and later applied to manipulation of the lion head mask and beating the drum.

6 During my fieldwork, there were no female drummers, because only men traditionally perform the lion dance. These gender boundaries were softening, and three females were learning lion dance and percussion but had not yet achieved sufficient proficiency on the drum to give performances. 
Johnson's idea of cognitive image schemas proposes that people understand a wide variety of phenomena through a general grasp of force, and I was familiar enough with the broad schema to recognize that the finer points of Master Paul's whipping-type kung fu force were eluding me. It was not until I studied calligraphy at the Chinese University of Hong Kong in 2012 that this force began to make sense to me. Writing Chinese characters with an ink brush requires the same sort of smooth flow toward a quickened final contraction, which I observed contained a slight slowing before the acceleration. Dance scholar Yatin Lin (2010) has also remarked on the type of force I am describing, which she has identified in not only Chinese calligraphy and martial arts, but also contemporary Chinese dance in Taiwan. Flowing movement punctuated by a slight deceleration before suddenly gathering speed at the end appears to be an unspoken aesthetic understanding shared through the force schema. Viewed another way, it suggests an economical logic of practice such that, once acquired, the structures of embodied Chinese being-in-the-world are generalizable across various cultural activities (Bourdieu 1977, 1990).

Kung fu drummers apply the Chinese force schema in two main ways. The first is as a matter of technique. One senior Hong Luck member told me that I needed to drum as if I were punching while another suggested that I wield the drumsticks the way I would handle a pair of swords. Implicitly, both these comments were about applying a Chinese kung fu force schema to drumming. That is to say, Hong Luck's drummers aim for looseness, slowing and relaxing between accelerations to a sharp snap at the point of contact, exerting the necessary force to play in a martially appropriate style that is both loud and fast. Relaxation with tension on impact may be common to the technique of many drumming styles around the world, but what is significant is that Hong Luck members take a martial stance on drumming that references the Chinese force schema.

The second way that kung fu drummers engage with a Chinese force schema is in musical sound. Whereas in most Western music the strongest beat in a bar is the first, in Chinese kung fu and lion dance percussion the downbeat falls at the end of phrases. In fact, this type of percussion music does not follow a metric pattern of strong and weak beats at all, 7 but rather is based on phrases of varying length. Whether in a short pattern that is repeated many times, a longer phrase in the middle of a section, or a rhythmic cadence that marks the closure of a larger musical unit, the music flows until a gathering of energy punctuates the final stroke. Acceleration toward downbeats is subtle, particularly when one phrase follows another, and it does not unduly affect a basically steady tempo; however, drummers slightly exaggerate the auditory force schema at the end of structurally significant sections by slowing down a bit on the beat before they accelerate to the final emphasis, which tends to even out any temporal disruption. Performances of martial arts exhibit a similar slowing-before-speeding to

7 For an example of another unmetered, phrase-based style of Chinese percussion, see Boyu Zhang's (1997) work on the gong and drum music of Jiangsu Province. 


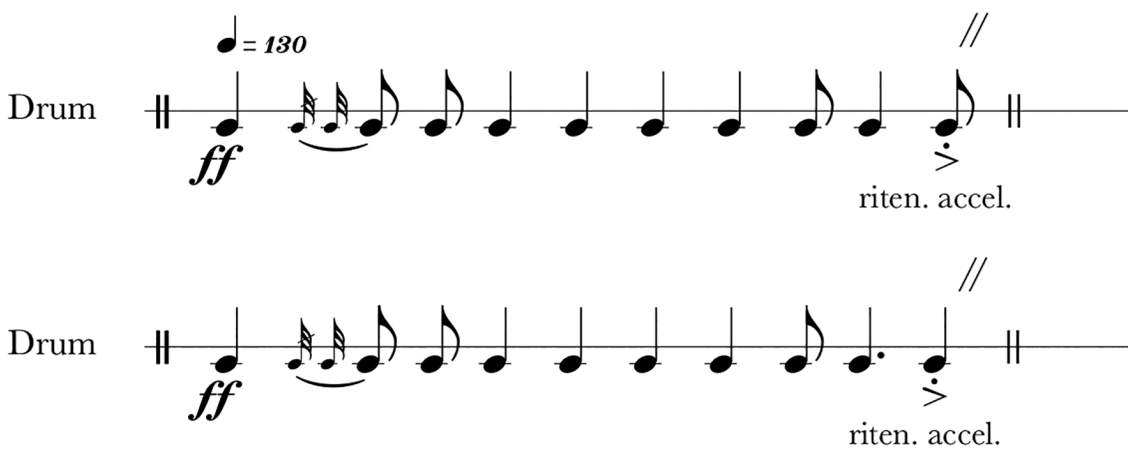

Figure 1: Two cadential lion dance drum patterns

emphasize the final strike of a fighting combination, albeit with more tolerance for exaggeration than there would be in music.

Figure 1 is my transcription of a cadential drum pattern for lion dancing, showing the rhythmic effect of the Chinese force schema. The first and second line are separate iterations and demonstrate how sudden slowing and final acceleration can result in displacement of the final beat. The gong player and cymbalist in a lion dance ensemble have the luxury of watching the drummer for bodily clues about how the timing will unfold. The lion dancers, however, rely on their ears, and the drummer watches their movement, so that coordination may be achieved.

As Becker and Becker have observed about the iconicity of gamelan's musical structure with Javanese cultural ideals of cyclic coincidence, musical systems are "instances of the way specific people understand and relate to the phenomenal world" $(1981,213)$. The Chinese force schema is powerful because it is interconnected with other aspects of culture in a coherent web of meaning. A further example relates the manipulation of space-time gesture in martial arts, drumming, dance, and calligraphy to a type of strategy. In Sun Tzu's The Art of War, an influential Chinese military manual from ancient times (2003), ${ }^{8}$ the tactical importance of delaying action until one knows the enemy's position, numbers, strengths, weapons, formations, motivations, etc., is repeatedly emphasized. Whether completing a calligraphic brush stroke, rhythmically marking the end of some lion dance choreography, or delivering a final blow in combat, a subtle slowness before acceleration to an emphatic finish is a culturally coded strategy, providing just enough time to make a last-minute adjustment according the situation.

8 As a public domain work, The Art of War is freely available in several places online, such as: http://classics.mit.edu/Tzu/artwar.html. 


\section{History, Community, and Identity}

Before describing three of my consultants' approaches to negotiating Chinese Canadian identity, I will first set the scene with some historical context. There have been Chinese people in Canada since before Confederation in 1867, but their experiences in this country have often been difficult (Lai 2011). The original migrants famously helped build the western portion of the railroad that eventually connected Canada together from coast to coast. According to sociologist Peter Li, however, Euro-Canadians saw Chinese people as a source of cheap labour-not as potential citizens ( $\mathrm{Li} 1998,30$ ). Immigration policies prevented them from bringing their families with them, leading to primarily male sojourner communities. In an effort to discourage Chinese people from coming to Canada after the railroad was completed, the government imposed a "head tax" in 1885 that was not applicable to any other nationality or ethnicity. This discriminatory levy increased several times before the Chinese Immigration Act of 1925 (a.k.a. the Chinese Exclusion Act), which essentially closed Canada to people from China (with a few exceptions). Despite their early contributions to nation-building, Chinese Canadians had neither suffrage nor access to professional designations (i.e., they could not be lawyers or doctors) until the repeal of the Chinese Immigration Act after the Second World War. Euro-Canadians also subjected them to social and economic exclusion, sometimes even perpetrating racially motivated violence. The lot of Chinese people in (now) officially multicultural Canada has improved since the dark days of legally institutionalized racism that was enshrined in the Exclusion Act. Nonetheless, social and systemic racial discrimination have not been eradicated, and they continue to exert a durable influence on the everyday existence of Chinese Canadians (as well as other racialized groups).

In 1961, Master Paul Chan and his associates formed the Hong Luck Kung Fu Club, deploying a multi-pronged strategy to improve their local Chinatown. Through martial arts, they disseminated self-defence skills to the local Chinese Canadian community, which proved useful for practitioners to protect themselves and their businesses. Hong Luck also began building bridges to non-Chinese Canadians through both teaching and performance. From the early days, Hong Luck was open to people of all backgrounds, which one of the founding members told me was an important way of establishing common ground-despite barriers of language and culture. As an inseparable aspect of their kung fu, Hong Luck does Southern-style lion dance, which uses martial movement and sound to disperse negative energy, thereby auspicating beginnings, such as weddings, store openings, and the New Year (Hu 1995; McGuire 2015; Slovenz 1987). Over time, performing the lion dance has been the most public aspect of Hong Luck's practices, with performances often occurring on the streets where passers-by can experience an important aspect of Southern Chinese culture. Hong Luck's stance on kung fu (including lion dance and percussion) shows its flexibility; club members have used their interdisciplinary blurred genre of martial arts for not only self-defence, but also for inclusion and diplomacy. 
The sociological interpretation of Toronto's Chinatown provided by anthropologist Richard Thompson is a useful frame for contextualizing the Hong Luck Kung Fu Club: "Chinatown may be viewed as a social system, separate from but linked to the larger Canadian system, consisting of a set of social positions and their corresponding roles" $(1989,26)$. In this sense, Hong Luck members who are active as students, teachers, and performers play a role in Chinatown society, helping to construct Chinese-ness in diaspora. For example, during my early days in Hong Luck's beginner classes, one of my teachers explained his identity as a Chinese Canadian to me with an analogy. $\mathrm{He}$ said, "I'm only Chinese when I'm at Hong Luck," but the rest of the time he felt and acted very "Canadian" or "white" because his lifestyle (interests, activities, language, and diet) was non-Chinese in everyday life. He then explained that he considered himself a "banana," which is yellow on the outside and white on the inside. Furthermore, my teacher told me that I am the opposite-an "egg"-because of my European heritage combined with my interest in Chinese culture, both at Hong Luck and beyond. His choice of metaphor juxtaposes external skin colour with the interiority of being-in-the-world, but also indicates the contingency of identity in a multicultural society. An "egg and banana" stance on the junction of ethnicity, heritage, culture, and affinity highlights how people reconstruct their being through the practices that they keep, but it also showcases the success of Hong Luck's mandate to promote Chinese culture for Canadian people of all backgrounds.

Metaphorical eggs and bananas also speak to the legacies of racism, where some Chinese Canadians keep their cultural activities hidden from people who might discriminate against them. For example, one of my lion dance teachers asked that I provide him a degree of privacy in my research. While he was comfortable appearing in my writing under the pseudonym Noah and having pictures or video taken, he preferred not to be named or to have personally identifying information revealed. His stance on anonymity became more apparent when another Hong Luck member tagged my teacher in a Facebook picture from a lion dance performance. Noah became angry and demanded that his name be removed from the image because he did not want his non-Chinese friends from school to know that he participated in Chinese culture. He told me, "They don't think I even speak Chinese." Clearly, he was concerned about what they would think, but he claimed his friends were not racist, just that "they wouldn't understand." Nonetheless, Noah's twenty-plus years at Hong Luck demonstrated a stance on his Chinese cultural heritage that showed he valued it-even if he felt the need to keep it compartmentalized from other parts of his life.

In contrast, my other lion dance teacher, David Lieu, took a more emphatically and publicly pro-Chinese stance. For starters, he preferred that I acknowledge him by name for his contributions to my research. Most of his friends were Asian, and when we first met at Hong Luck (before he started teaching me), he commented that he did not have much time or energy for people who did not appreciate Chinese culture. After several years of training and, eventually, performing together, he told me that I was not so bad, because I had shown 
him an understanding of Chinese culture that he felt most Euro-Canadians lacked. I once asked him if he ever experienced racism, to which he replied that there were no minorities in his social circles because there were people of all different backgrounds, which upholds Toronto's reputation for being cosmopolitan. David also told me that he had occasionally provided kung fu "education" to people who used racial slurs, but that he considered them to be ignorant and thus incapable of affecting his self-esteem. His stance on racism categorically rejected the proposition of any intrinsic inequality, leaving no room for it in his life-world. Notwithstanding the persistence of social discrimination against Chinese people in Toronto (Chan 2011, 265), kung fu has proven a powerful tool for resisting racism both physically and psychologically. For David, martial arts, lion dance, and especially drumming are avenues for him to express and celebrate his Chinese-ness, empowering a pride that is impervious to the effects of racial intolerance.

From the stances of my consultants, we can see that kung fu's blurred genre is intimately tied to how they construct and reconstruct their identities as Chinese Canadians. Lion dance and percussion music are particularly powerful in this regard because they are public activities, allowing dancers and musicians to perform Chinese-ness for both insiders and outsiders of the culture (see Wu 2015 for a British comparison). Moreover, lion dance patrons who pay for performances are able to enjoy similar benefits by connecting their patronage to a public expression of identity. Whereas the lion dance's traditional ritual function is to auspicate liminal moments (Feltham 2009), in contemporary Canadian society it is equally used with regards to the liminality of identity. To be liminal refers to the state of being at a limen, i.e., a threshold; Hong Luck's dancers and percussionists cross the limen into a heightened performative space of Chinese-ness when they are involved with the lion ritual. Given the deplorable history of discrimination against Chinese people in Canada, it is no surprise that some lion dancers are happy to cross back into a less Chinese mode of embodiment when the performance is done. Others, however, revel in their heritage identity through lion dance and percussion in a way that pushes the limen out into their everyday lives. Some drummers, for example, are notorious for beating out lion dance rhythms with their hands on any available surface at home, work, and school, as well as during commutes on public transit and even at social events.

As expressive martial arts, it matters that Hong Luck's lion dance and percussion music are performed in a way that embodies and auralizes a kung fu ethos so that they can enact resistance. Practitioners consider the lion dance to represent the spirit of a kung fu club, and the drum functions as the lion's roar. In contradistinction to lingering nineteenth- and early-twentieth-century depictions of China and her people as weak and sickly, powerful sound and movement in lion dance as martial arts perform strength (Morris 2000). In this way, Hong Luck's lion dancing and percussion are a form of self-defence against symbolic violence. The ability of powerful drumming to counter negative stereotypes about Asian (North) Americans more generally has also been observed of taiko (Yoon 2001). However, the direct connection of lion 
dance to kung fu through homologous footwork and stances, as well as the percussion's historical origins as battlefield instruments, further enhances the performance's ability to fight discriminatory perceptions.

\section{Conclusion}

As Master Paul Chan told me, culturally acceptable performances of kung fu, lion dancing, and martial percussion require movement and sound with Chinese characteristics. Practitioners at the Hong Luck Kung Fu Club learn to embody this cultural identity, but they deploy Chinese-ness in diverse ways. Significantly, the club's membership reflects Toronto's multicultural population, and members of all backgrounds become part of Chinatown society through their participation in these practices. In this article, I have argued that correct performances use a centred horse stance to issue flowing force with a slow-then-fast gathered snap at the end. Physical stances undergird stances on embodied meaning, while the Chinese force schema integrates into a culturally coherent system of iconicity. Hong Luck members and their Chinatown patrons treat these characteristics, among others, as explicitly Chinese, providing practitioners with an embodied pathway towards constructing and manifesting diasporic identity. Regardless of how people grapple with this identity relative to broader Canadian society, Hong Luck leaves an indelible mark on the people who train there-and the audiences who view their performances.

\section{REFERENCES}

Becker, Judith, and Alton Becker. 1981. "A Music Icon: Power and Meaning in Javanese Gamelan Music." In The Sign in Music and Literature, edited by Wendy Steiner, 2013-15. Austin, TX: University of Texas Press.

Berger, Harris. 2009. Stance: Ideas about Emotion, Style, and Meaning in the Study of Expressive Culture. Middletown, CT: Wesleyan University Press.

Boretz, Avron. 2011. Gods, Ghosts, and Gangsters: Ritual Violence, Martial Arts, and Masculinity on the Margins of Chinese Society. Honolulu, HI: University of Hawai'i Press.

Bourdieu, Pierre. 1977. Outline of a Theory of Practice. Translated by Richard Nice. New York: Cambridge University Press.

—. 1990. The Logic of Practice. Translated by Richard Nice. Stanford, CA: Stanford University Press.

Chan, Arlene. 2011. The Chinese in Toronto from 1878: From Outside to Inside the Circle. Toronto: Dundurn.

Downey, Greg. 2002. "Listening to Capoeira: Phenomenology, Embodiment, and the Materiality of Music." Ethnomusicology 46 (3): 487-509.

Downey, Greg, Monica Dalidowicz, and Paul H. Mason. 2014. "Apprenticeship as Method: Embodied Learning in Ethnographic Practice." Qualitative Research 15 (2): 183-200.

Feltham, Heleanor B. 2009. "Everybody Was Kung-Fu Fighting: The Lion Dance and Chinese National Identity in the 19th and 2oth Centuries." In Asian Material Culture, edited by Marianne Hulbosch, Elizabeth Bedford, and Martha Chaiklin, 103-40. Amsterdam: Amsterdam University Press. 
Geertz, Clifford. 1980. "Blurred Genres: The Refiguration of Social Thought." American Scholar 49 (2): 165-79.

Green, Thomas A. 2003. "Sense in Nonsense: The Role of Folk History in the Martial Arts." In Martial Arts in the Modern World, edited by Thomas A. Green and Joseph R. Svinth, 1-11. Westport, CT: Praeger.

Henning, Stanley E. 1999. "Academia Encounters the Chinese Martial Arts." China Review International 6 (2): 319-32.

Hong Luck Kung Fu Club. 2016. "Chinese Lion Dance @ Wedding in Toronto, Ontario, Canada." YouTube video, 4:31. http://youtu.be/wAKfjYocBvk.

Hu, William C. 1995. Chinese Lion Dance Explained. San Francisco: Ars Ceramica.

Husserl, Edmund. (1913) 1962. Ideas: General Introduction to Pure Phenomenology. Translated by W. R. Boyce Gibson. New York: Collier Books.

Johnson, Mark. 1987. The Body in the Mind: The Bodily Basis of Meaning, Imagination, and Reason. Chicago: University of Chicago Press.

1997/8. "Embodied Musical Meaning." Theory and Practice 22/3:95-102. Judkins, Benjamin N., and Jon Nielson. 2015. The Creation of Wing Chun: A Social History of the Southern Chinese Martial Arts. Albany, NY: SUNY Press.

Lai, David Chuenyan. 2011. A Brief Chronology of Chinese Canadian History: From Segregation to Integration. Burnaby, BC: David See-Chai Lam Centre for International Communication, Simon Fraser University.

Li, Peter. 1998. The Chinese in Canada. 2nd ed. Toronto: Oxford University Press.

Lin, Yatin. 2010. "Choreographing a Flexible Taiwan: Cloud Gate Dance Theatre and Taiwan's Changing Identity." In The Routledge Dance Studies Reader, 2nd ed., edited by Alexandra Carter and Janet O'Shea, 2250-60. New York: Routledge.

Lorge, Peter. 2012. Chinese Martial Arts: From Antiquity to the 21st Century. New York: Cambridge University Press.

McGuire, Colin. 2015. "The Rhythm of Combat: Understanding the Role of Music in Performances of Traditional Chinese Martial Arts and Lion Dance." MUSICultures 42 (1): 1-23.

Morris, Andrew. 2000. "To Make the Four Hundred Million Move': The Late Qing Dynasty Origins of Modern Chinese Sport and Physical Culture." Comparative Studies in Society and History 42 (4): 876-906.

Paetzold, Uwe U., and Paul H. Mason, eds. 2016. The Fighting Art of Pencak Silat and Its Music: From Southeast Asian Village to Global Movement. Leiden, The Netherlands: Koninklijke Brill NV.

Rice, Timothy. 2003. "The Ethnomusicology of Learning and Teaching." College Music Symposium 43:65-85.

Shahar, Meir. 2008. The Shaolin Monastery: History, Religion, and the Chinese Martial Arts. Honolulu, HI: University of Hawai'i Press.

Slovenz, Madeline Anita. 1987. “'The Year Is a Wild Animal': Lion Dancing in Chinatown.” Drama Review 31 (3): 74-102. 
Sun, Tzu. 1988. The Art of Strategy: A New Translation of Sun Tzu's Classic The Art of War. Translated by R.L. Wing. New York: Dolphin/Doubleday.

- 2003. The Art of War: Complete Texts and Commentary. Translated by Thomas Cleary. Boston, MA: Shambhala Publications.

Thompson, Richard H. 1989. Toronto's Chinatown: The Changing Social Organization of an Ethnic Community. New York: AMS.

Walser, Robert. 1991. "The Body in Music: Epistemology and Musical Semiotics." College Music Symposium 31: 117-26.

Wing, R.L., trans. 1988. The Art of Strategy: A New Translation of Sun Tzu's Classic The Art of War. New York: Dolphin/Doubleday.

Wong, Deborah. 2008. "Moving: From Performance to Performative Ethnography and Back Again." In Shadows in the Field: New Perspectives for Fieldwork in Ethnomusicology. 2nd ed., edited by Gregory Barz and Timothy J. Cooley, 76-89. New York: Oxford University Press.

Wu, Wanting. 2015. "Dancing with Lions: The Assertion and Transformation of Chinese Community and Identity in Belfast." Queen's Political Review $3(1): 113-21$.

Yoon, Paul Jong-Chul. 2001. “'She's Really Becoming Japanese Now!': Taiko Drumming and Asian American Identifications." American Music 19 (4): $417-38$.

Zhang, Boyu. 1997. "Mathematical Rhythmic Structure of Chinese Percussion Music: An Analytical Study of Shifan Luogu Collections.” PhD diss., Turku University.

\begin{abstract}
The Hong Luck Kung Fu Club has been a fixture of Toronto's Chinatown for over fifty years. Its curriculum includes not only self-defence skills, but also percussion music for accompanying martial arts demonstrations and lion dancing. Hong Luck's blurred genre is a tool for preserving, transmitting, and promoting culture. At the same time, practitioners negotiate their identities in diverse ways. I thus interpret kung fu as a flexible, embodied practice whose purview extends beyond physical combat. Based on fieldwork at Hong Luck, this article uses cognitive semantics and phenomenology to demonstrate that kung fu, lion dance, and percussion help (re)construct Chinese identities emergently and strategically.
\end{abstract}

\title{
RÉSUMÉ
}

Le club de kung-fu Hong Luck est une institution phare du quartier chinois de Toronto depuis plus de cinquante ans. Son programme inclut non seulement des cours d'autodéfense, mais également des cours de percussion pour l'accompagnement des démonstrations d'arts martiaux et de danse du lion. Le style fluide du club Hong Luck est un outil important dans la préservation, la transmission, et la promotion d'un patrimoine culturel. Les membres y négocient simultanément leurs identités de différentes façons. J'interprète donc le kung-fu comme une pratique flexible et dont la portée dépasse le combat physique. À partir d'une enquête de terrain au club Hong Luck, cet article 
emprunte à la sémantique cognitive et à la phénoménologie afin de montrer que le kung-fu, la danse du lion, et la musique de percussion contribuent à (re)construire les identités chinoises dans leurs aspects émergents et stratégiques.

\section{BIOGRAPHY}

Colin McGuire holds a PhD in ethnomusicology and a graduate diploma in Asian studies from York University. His research investigates the intersection of music and martial arts, focusing on how meanings are embodied in combative relationships of sound and movement. Previously, McGuire was a Government of Ireland Postdoctoral Fellow in the Department of Music at University College Cork, and he has published on the percussion used by practitioners of Chinese kung fu and lion dance in Canada, as well as the anthemic qualities of the most famous song in Hong Kong martial arts cinema. By hearing music as martial arts and listening to martial arts as music, McGuire contributes to broader discussions of diaspora, community, and identity. 